\title{
Nominations Sought
}

\section{FOR \\ 1996 APSA Career and Dissertation Awards}

Nominations are invited for APSA Career and Dissertation Awards to be presented at the 1996 Annual Meeting, August 29 - September 1 at the San Francisco Hilton and Towers.

Departments are invited to submit nominations for dissertation prizes although not more than one submission per award. Dissertations eligible are those completed and accepted during the past two calendar years. Department submissions should be sent to each member of the award committee and include a letter of nomination and a copy of the dissertation. Departments must submit their nominations by January 15, 1996.

Individuals are invited to submit, for consideration, letters of nomination for Career Awards. Career Awards are decided upon by three-member committees appointed by the President and approved by the Council. The deadline for submission of letters is January 31, 1996.

APSA Career and Dissertation Awards are listed below:

\section{Dissertation Prizes}

Gabriel A. Almond Award - in the field of comparative politics.

William A. Anderson Award - in the field of intergovernmental relations.

Edward S. Corwin Award - in the field of public law.

Harold D. Lasswell Award - in field of policy studies.

Helen Dwight Reid Award - in the field of international relations, law and politics.

E.E. Schattschneider Award - in the field of American government.

Leo Strauss Award - in the field of political philosophy.

Leonard D. White Award- in the field of public administration.

\section{Career Awards}

John Gaus Award and Lectureship - to honor a recipient's lifetime of exemplary scholarship in the joint tradition of political science and public administration and more generally, recognizes achievement and ecourages scholarship in public administration.

James Madison Award and Lectureship - to honor an American political scientist who has made a distinguished scholarly contribution to political science. The award is designed to recognize a career of scholary excellance rather than a particular piece of scholarship.

Hubert H. Humphrey Award - in recognition of notable public service by a political scientist.

Carey McWilliams Award - to honor a major journalistic contribution to our understanding of politics. 